\title{
DO THE ENGINEERING EDUCATION INSTITUTIONS PROVIDE SOFT SKILLS EDUCATION? VIEWS OF SOUTH AFRICAN ENGINEERING PROFESSIONALS
}

\author{
F. Munir
}

Department of Applied Language Studies

Nelson Mandela University

Port Elizabeth, South Africa

https://orcid.org/0000-0001-8055-9768

\section{ABSTRACT}

Engineering is a profession that utilises knowledge of mathematics and science in order to find solutions to multifaceted problems for the benefit of humans. The advancement of a knowledgebased economy within a globalised world means engineering education institutions are responsible for producing graduates who possess exceptional technical and soft skills. With the universities preferring to provide traditional education and the global corporations looking for versatile graduates, the question arises who is responsible for providing the soft skills education to engineering students of the $21^{\text {st }}$ century. The present study explores qualitative and quantitative data from engineering professionals across South Africa to determine their views on the teaching of soft skills in the engineering curriculum at the engineering education institutions. The data revealed that the engineering professionals are not satisfied with their soft skills training at the educational institutions and would like more focus on such education. The study has implications for the engineering education institutions to balance technical knowledge with soft skills training in their curricula to meet the requirements of the industry. Such education should be incorporated across the board into their professional training. This will result in empowered graduates who are able to carve their own path to professional success.

Key words: soft skills, soft skills education, engineering education, engineering professionals

\section{INTRODUCTION}

"Change is a constant in society and engineering helps to drive change and is driven by it" (Galloway 2008, ix).

Although engineering is a technical profession, it cannot be separated from its relationship with society in general. Engineers constantly create and innovate technology for the service of those who use it. The Engineering Council of South Africa (ECSA 2020, 1) defines engineering to be the practice of science and technology in an effort to find solutions to "problems of economic importance and those essential to the progress of society". These solutions, while being 
dependent on scientific and engineering knowledge, "must take into account the needs of society, sustainability and the protection of the physical environment" (ECSA 2020, 1). Engineers require adequate mathematical ability; however, they also "have to be imaginative, responsible, creative, and they must be very good at working with all sorts of other people. Geography, economics, art, history, modern languages, psychology, as well as the traditional maths and physics can all help you to become an excellent engineer" (Darby 2020, 1).

With the rapid development and expansion taking place globally in the $21^{\text {st }}$ century, there are also issues of fierce competition and high levels of unemployment. To remain relevant and marketable in today's world, engineers not only have to keep thinking innovatively in terms of their products, but also adopt a responsive and flexible approach in their personalities to better deal with the challenges of globalisation. We are living in a highly connected, borderless and complex world and engineering education cannot be detached from the reality of an engineer who has to address "problems never seen before in a world that is open and competitive" (Nasr 2014, 16).

The impact of engineering on our lives has been such that it is hard to imagine a life without computers, mobile phones, printers, the Internet, wireless connectivity and the like. Without doubt, engineers have been at the helm of all this transformation. The design and development of all these products require knowledge across several disciplines. Interdisciplinarity has become critical to the survival of engineers in today's world, thereby challenging educational norms of the past century. The Engineer of 2020 report by the National Academy of Engineering $(2004,2)$ poses some very pertinent questions in this regard:

Can the engineering profession play a role in shaping its own future? Can a future be created where engineering would be recognised in addressing societal and technical challenges? How can engineers best be educated to be leaders and be able to balance the gains afforded by new technologies with the vulnerabilities created by their by-products without compromising the well-being of society and humanity? Will engineering be viewed as a foundation that prepares citizens for a broad range of creative career opportunities? Will engineering reflect and celebrate the diversity of all the citizens in our society? Amadei $(2004,27)$ provides the following definition of the engineer of the future:

"The engineer of the future applies scientific analysis and holistic synthesis to develop sustainable solutions that integrate social, environmental, cultural, and economic systems."

Global engineering projects cover diverse countries and cultures and give rise to challenges of leadership, cross-cultural management, legal and managerial responsibilities and interorganisational relationships. "From the perspectives of the global labor market and global 
employers of engineers, the fundamental issues for engineering education seem to be connected with the differences between the requirements of the employers and the knowledge and skills given by universities." (Miszalski 2014, 44). While the engineering education institutions still prefer the traditional professional profile, transnational corporations require supplementary knowledge and skills.

In other words, engineers of the $21^{\text {st }}$ century should be capable of integrating their scientific and technological knowledge in several disciplines with their soft skills in order to arrive at sustainable solutions and to be effective human beings within a globalised society.

Bradford (2017) argues that technical skills are important for engineers in their technical roles; however, soft skills are also important. These skills are required by both the employees and the employers (Carey 2019). It would be unwise to ignore them when searching for employment or for looking for ways to advance one's career. Carey $(2019,1)$ and Fourtané (2019) identify the following soft skills for a successful career in engineering:

\section{Communication}

Regular and effective communication is crucial for engineers because projects will suffer if there is a breakdown in communication among executives, managers, team members and customers. When technical and soft skills are not balanced in a project, "then financial capital and human capital do not pay the returns for which one hopes" (Kaipa et al. 2005, 2). Poor communication skills impede an engineer's progress. On the other hand, an individual's technical skills could be mediocre, but if she/he has good communication skills, she/he would be valued in an organisation (Visser, Naude, and Scheper 2004).

\section{Collaboration}

Whether it is cooperation, collaboration or teamwork, nowadays an engineer has to work with people from different backgrounds. An engineer does not work independently, but with a team of engineers from different disciplines as well as with support staff - all working together to complete one project, sharing responsibility and accountability as a group (Cisco Career Guidance 2014).

\section{Leadership}

Teichmann et al. $(2013,44)$ define leadership as the ability of "developing, engaging, and inspiring others to bring to life a common vision" by means of "sharing perspectives and developing and maintaining trust". Passow (2007) considers leadership to be one of the key competences for an engineering programme. A leader is determined to achieve a certain vision 
and is able to inspire others to achieve that vision as well. A leader accomplishes this with the help of a positive attitude, exceptional communication skills and a continuous nurturing of others' potential.

\section{Creativity}

Teichmann et al. (2013) argue that innovation is the departure from an old way of doing something and replacing it with a new one. In other words, innovation is positive change. Entrepreneurs recognise and exploit the trends in a market and focus on finding breakthrough solutions to problems by employing new ideas and strategies. Innovation helps them to develop new products and services based on the analysis of clients' needs, thus securing a market niche. "Design engineers are enablers of innovation" (May and Strong 2006, 206).

\section{Adaptability}

Engineers are required to change and adapt their designs and products according to the changing circumstances around them. "An engineer with good adaptability skills is able to identify solutions to unforeseen problems. Then, the engineer can make the necessary modifications to adapt to the new situation or new environment" (Fourtané 2019, 1).

Engineers possessing soft skills will be able to solve the problems encountered by humanity, creatively and critically. In other words, engineers require education and training in the application of their soft skills just as much as they do in their technical skills

In order to incorporate soft skills, there is a growing focus on the change required in engineering education. In addition to the knowledge base, the professional ability of an engineering professional should also include personal abilities and aspects of character which enable them to perform better in particular situations. Therefore, an emphasis is required on teaching not only what they should know, but also on creating an awareness of what they should know about themselves (Llorens-Garcia, Linas-Audet, and Sabate 2009). We need to invest in soft skills education and training to remain relevant in a borderless, competitive world (Camuti 2006).

This study reports on data from 60 engineering professionals in South Africa on their views about the responsibility of soft skills education for engineering graduates.

\section{REVIEW OF THE LITERATURE}

Engineering is expected to remain the most impactful of all professions in shaping the life we will live tomorrow. Engineering has been the biggest contributor to the quality of life we enjoy today and hope to enjoy in the future. However, with opportunity comes responsibility. 
Engineering is a profession which can play both parts: that of being the saviour as well as the destroyer. Globalisation, while being the catalyst for exciting opportunities and new technologies, is also the major cause of the planet's deterioration in the form of global warming. "Global warming is the rise in temperature of the earth's atmosphere. It is said that by the time a baby born today is 80 years old, the world will be six and a half degrees warmer than it is now" (BBC News 2014, para. 1).

An ever growing population has led to increased industrial activity and the need for housing and transportation requirements. Resultant effects have been extensive pollution, resource depletion and species extinction.

Increasing population impoverishes biodiversity. Many plant and animal species have become extinct in the past decades. One cannot directly link globalisation to the disappearing biodiversity; however, human activities of habitation, the quest for new commodities, the pursuit of greater connectivity, farming and mining have polluted and destroyed several ecosystems (Huwart and Verdier 2013).

Population expansion and the resulting increase in industrial activity have implications for the engineering profession. Engineers are the backbone of industrial activity which is directly linked to $\mathrm{CO}_{2}$ production and, in turn, to global warming. They have to understand the impact of their professional decisions on the environment and resource diminishment. Instead of contributing to the environmental disaster, they can be instrumental in finding ways for the sustainable development of the present without compromising the future. Concern for biodiversity and the environment is part of accountability, an important soft skill.

Besides being environmentally accountable, engineers have to be conscious of the character they display in their daily functions. Since engineering is considered to be a publicserving profession, engineers have to uphold this stature in their dealings with their colleagues and clients, as well as the general public. Moore and Voltmer (2003) assert that as professionals, engineers hold a position of trust and are expected to conduct themselves ethically in their occupation.

Many developed countries now have to compete with the economies of developing nations such as Brazil, Russia, India and China, also known as the BRIC nations. These countries are producing a record number of new engineers every year. A Stanford University study (2013) found that BRIC countries are spending huge amounts on their engineering colleges in order to form world-class institutions so that their graduates would be able to compete with those from the developed nations. "More specifically, of the nearly 200,000 engineers emerging from elite programs in BRIC countries each year (as of 2009 - by 2013, the number is much larger), the top 100,000 are comparable to the top 50,000 engineers receiving bachelor's degrees from U.S. 
colleges and universities, the top 150,000 engineering graduates annually in the European Union, and the top 50,000 engineering graduates annually in Japan" (Stanford University 2013, 19). In comparison, South Africa produced only 9,387 engineering graduates in 2011 (Esterhuizen 2013, para.1).

These statistics certainly pose two problems for the countries which want to compete in the international engineering market: firstly, to produce sufficient numbers of engineers and secondly, to produce a new kind of engineer. "The long-term implications of a failure to confront this situation are self-evident" (The Royal Academy of Engineering 2007, 5). Major engineering companies today such as BMW, VW, Samsung, Sony, Bosch and many others have a worldwide presence. Therefore, the challenge of fierce global competition cannot be avoided.

Graduates of the future will need to make decisions in a socio-geo-political environment which would be arguably different from that of the present. "In their lifetimes, engineering students now attending college can expect to see" a further increase in world population, "major global warming phenomena, and major losses in biological and cultural diversity on Earth" (Amadei 2004, 25).

Steiner (2004) argues that in this progressively complex and connected world, where science and technological innovation are on the rise, socio-technical problems are widespread. Solutions to today's problems require a new outlook in a global context. Engineers have to work on technically perplexing, open-ended design problems around significant modern-day issues, for example, designing ground-breaking technology in several fields such as medicine, communication, sports, mining, entrepreneurship, manufacturing, alternative energy, environmental conservation and the like. They not only have to consider creative, out-of-thebox solutions, but all the restraints on their proposed solutions as well. Resources, time limitation, scope and the impact of the solutions have to be carefully considered.

In the interest of finding solutions to complex problems and of satisfying certain consumer demands, companies nowadays have to work in partnerships (Camuti 2006). For example, companies such as Siemens have projects involving teams from the U.S., Brazil, Germany, India and Ireland. These projects do not only require exceptional technical skills, but also require an understanding of diverse cultures and traditions in different settings.

Engineering professionals are regularly required to work globally in multidisciplinary teams. Hence, the importance of communication skills in the engineering profession cannot be emphasised enough. From daily conversations and emails to more formal contexts, engineers urgently require these skills. If they were to rely solely on their technical skills, they would not be able to complete their team projects and would probably be left with serious misperceptions and loss of time, capital and even their jobs. On the other hand, effective communication skills 
will not only result in project goals being successfully accomplished, but also in productive relationships with their employers, co-workers and clients.

Khalid et al. (2013, 3-4) identify three primary challenges for today's engineering education:

- $\quad$ "It should be responsive to the changing needs of the engineering profession.

- It should transform the perception of engineering as a profession for technical people only.

- It should be able to retain its high-performing students by communicating the value of the engineering profession."

Engineering education institutions can achieve this transformation by including soft skills education in their curricula.

Freedman (2012, para. 3) relates a common perception among people about the engineering profession: "Anecdotally, we have all heard of the extremely intelligent individual who lacks the ability to work on team assignments, communicate with clients or maintain professionalism". Blesser (2009) also points out the reclusive nature of engineers. Many engineers would prefer to be left alone with their technical work. They lack soft skills needed to establish relationships with others and, as a result, avoid situations where they will require such skills.

A probable consequence of an exclusive focus on technical skills would be the dissatisfaction of prospective employers. One might argue that engineering undergraduates do not need additional focus on soft skills education as they are required to undertake experiential learning as part of their diploma/degree requirements. Moreover, their curricular schedules are already full to the limit and simply cannot adapt to extra demands. However, these experiential learning programmes are unable to adequately address the relevance and application of soft skills. This aspect is reported in many studies (Da Silva and Tribolet 2007; the Sustainable Engineering Society of Australia 2014; McCarthy 2013; Hodges and Burchell 2003; Hissey 2000; Del Vitto 2008).

\section{THE SOUTH AFRICAN CONTEXT}

Pauw et al. in their survey $(2006,15)$ on graduate unemployment in South Africa for the Development Policy Research Unit (DPRU), found that "many graduates lack soft skills and are not workplace ready when they start their careers in the corporate sector". Indeed, it is an important reason why many graduates fail to find employment in the first place.

Vermeulen (2013) reports that owing to the current state of the South African economy, companies are ignoring the training of employees in soft skills, which include social, 
communication and self-management behaviour, in favour of hard skills training. Soft skills are conducive to an employee's career growth within an organisation. When people do not advance in a company, the reason is usually a lack of soft skills. One needs emotional intelligence and communication skills to navigate through one's career. Even though soft skills are required by everyone in an organisation, South African companies are investing in soft skills training only for senior managers.

The report, Graduate Unemployment in Post-Apartheid South Africa, by the DPRU, University of Cape Town $(2006,26)$ identifies below par soft skills as one of the reasons for unemployment among young graduates, "Many graduates lack soft skills and are not workplace ready when they start their careers in the corporate sector. In fact, this was highlighted as a reason why many graduate are unsuccessful already in the recruitment phase." In addition, the report associates poor soft skills and high functional illiteracy with poor academic performance among students (DPRU 2006, 44).

Knobbs, Gerryts, and Roodt (2013) emphasise the gap of soft skills in the training of engineering graduates entering the mining industry. They argue that although these graduates are proficient in technical skills, they are often not adequately prepared for the intimidating world of work where their "highly-prized and hard-fought knowledge is not fully used or given the respect that graduates expect" (Knobbs et al. 2013, 56). They lack the soft skills necessary to tackle the people issues that are common in the workplace. This deficiency in their soft skills makes it difficult for them to adjust to the already unforgiving work environment.

Globalisation also means outsourcing of jobs from high wage to low wage countries (Camuti 2006, 3). Although China and India are benefitting most from this wave, it presents an opportunity for South African engineers to play an important role in the global economy. If our engineering undergraduates have a high level of technical knowledge as well as the value of soft skills, this will give them an edge to survive and grow in this age of globalisation.

\section{WHO IS RESPONSIBLE FOR SOFT SKILLS DEVELOPMENT?}

Students graduating from their higher education technical institutions might think that the companies that they will be working for will provide them with training in the soft skills necessary for their jobs. However, Hissey (2002) has pointed out that in the past some companies used to motivate employees by providing them with training in the necessary skills. But now the business landscape has changed. "The majority of executives said that their corporations now believe the responsibility for technical and personal development rests with the individual" and expected "their new engineers to possess skills over and above what they expected in the past" (Hissey 2002, para. 17-18) Even if they are fortunate to find internships, 
one must understand that not all internships will be able to address what the graduates require to thrive in their careers. If that is the case, the onus is on the educational institutions to provide their students with necessary competences before they graduate and start looking for employment.

Khalid et al. $(2013,4)$ note that in the majority of engineering schools across the United States, "few students experience any humanities, arts, communication, history or culture related classes in their engineering curricula". Those who do take such classes consider them irrelevant. The development of soft skills such as emotional literacy, social skills and interpersonal communication is considered unnecessary by the administration. As a result, most graduates tend to have few soft skills. There is a need for educational reform where soft skills can be emphasised, especially written and oral communication skills. "These skills can be taught without significant investment" (Khalid et al. 2013, 3).

Although developing soft skills is not difficult, it can be challenging. Some students might find it "as foreign as organic chemistry to a sociology major" (Freedman 2012: para. 13). However, it should not be seen as unattainable. The aim is to address our weaknesses to maximise our effectiveness (Freedman 2012). It is important for educational institutions to consult the human resource professionals to identify the knowledge and proficiencies necessary for a global engineer so that they can work on preparing their students for such roles. Incorporating these aspects into an engineering curriculum would ensure that their students would remain effective and competitive in the global environment.

Muller (2010) refers to Germany when emphasising the need for soft skills in engineering education. Germany is known for its state-of-the-art engineering technologies. German engineers and their products are in great demand the world over. This is also due to the fact they have kept pace with global changes. They pay more attention to customers' real needs and this has also impacted on the requirements for their engineering graduates. Soft skills are being given higher importance. They are required to have the ability to deal with people, to communicate, to offer convincing arguments and they have to do this all in excellent English. International companies seek engineering graduates with an ability to work across cultures; however, there has to be a balance and soft skills cannot be promoted at the expense of essential knowledge of engineering (Muller 2010, para. 9-10).

Del Vitto (2008) proposes that by investigating the best practices of international companies and the programmes developed by cross-cultural trainers, engineering schools can better develop their curricula, thus ensuring that their students have the necessary training as global engineers. However, Moore and Voltmer (2003) caution against a one-size-fits-all approach. They argue that while educators should think of preparing engineering graduates to 
remain productive for much longer in their professional careers in a changing environment, they should first focus on the conceptual foundations of producing a robust curriculum. From these guidelines, they can then create "their own unique curriculum that represents their strengths and interests. Moreover, the form of implementation will depend upon the local conditions as well" (Moore and Voltmer 2003, 453).

\section{METHODOLOGY}

In order to understand whether South African engineering institutions are adequately providing soft skills education or training to their graduates, sixty engineering professionals from across South Africa were asked to complete a questionnaire about their views of the curriculum that they had studied at their training institutions in South Africa. Ten of them were also interviewed using the same questions to gain a deeper understanding of the soft skills education. The questionnaire included quantitative as well as qualitative aspects.

The professionals who participated in the study were from a variety of engineering disciplines. All of them are based in South Africa. The professionals possessed a minimum qualification of the National Diploma in Engineering. Many of them had higher qualifications, such as the BTech or MTech. Their professional experience after graduation ranged from one year to more than 40 years.

For the purpose of eliminating any confusion regarding soft skills, the engineering professionals were also provided with information outlining different soft skills. The findings of the questionnaire are discussed below:

\section{Quantitative Data}

Table 1: Quantitative data from the questionnaires

\begin{tabular}{|c|l|c|c|c|c|c|}
\hline No & \multicolumn{1}{|c|}{ Statement/Question } & SD \% & D \% & N \% & A \% & SA \% \\
\hline 1 & Engineers need soft skills. & 0 & 0 & 0 & 24 & 76 \\
\hline 2 & I was taught soft skills in my engineering studies. & 10 & 40 & 8 & 38 & 4 \\
\hline 3 & Engineers need more focus on soft skills. & 0 & 6 & 2 & 46 & 46 \\
\hline 4 & $\begin{array}{l}\text { The engineering curriculum at training institutions does not } \\
\text { adequately provide students with soft skills education. Do you } \\
\text { agree? }\end{array}$ & 0 & 4 & 8 & 88 & 0 \\
\hline 5 & $\begin{array}{l}\text { Evaluate the curriculum that you studied to become an } \\
\text { engineer. Did it prepare you in terms of soft skills? }\end{array}$ & 60 & 24 & 6 & 10 & 0 \\
\hline 6 & $\begin{array}{l}\text { The engineering curriculum at training institutions should } \\
\text { include soft skills. Would you support this move? }\end{array}$ & 0 & 4 & 8 & 18 & 70 \\
\hline 7 & $\begin{array}{l}\text { Do you think all lecturers can contribute to the teaching of soft } \\
\text { skills? }\end{array}$ & 2 & 18 & 8 & 0 & 72 \\
\hline A: Agree, SA: Strongly Agree, DA: Disagree, SDA: Strongly Disagree, N: Not Sure & & \\
\hline
\end{tabular}




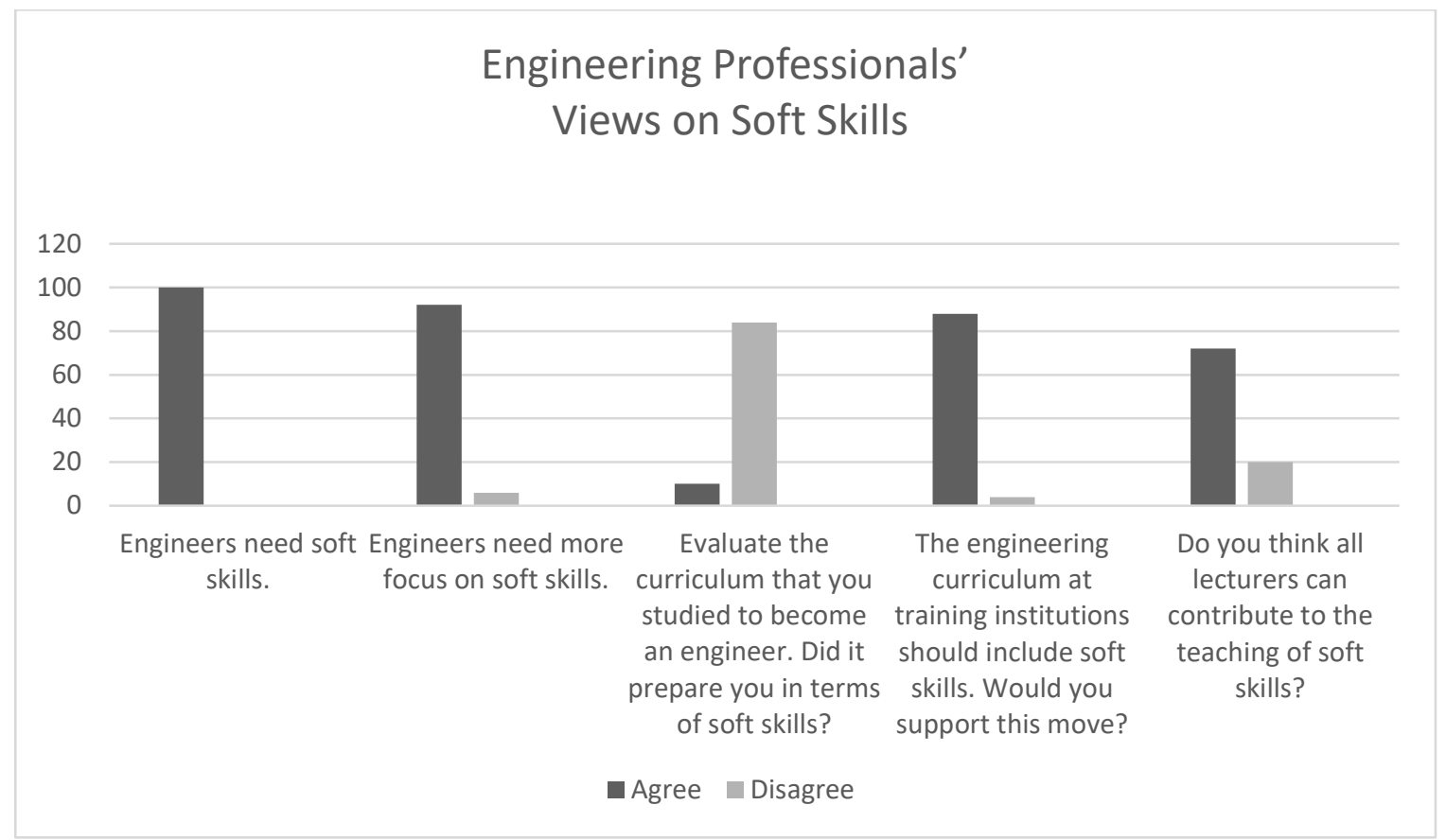

Figure 1: Engineering Professionals' Views on Soft Skills (condensed quantitative data)

\section{Qualitative Data}

Q1 Engineers need more focus on soft skills. Give reasons for your answer.

\section{In agreement:}

"Most engineers are concerned by the hard skills aspects of the profession only" (EP\#48).

"In general, the type of person predisposed to become an engineer will lack soft skills" (EP\#49).

\section{In disagreement:}

"If you are working on a project by yourself you don't need soft skills" (EP\#37).

"He is an engineer and not a manager" (EP\#25).

The above statements seem contradictory to what was revealed in the literature review, as well as in other data. Engineers work in multidisciplinary teams and sooner or later they are hired as managers in their careers. In addition, engineers would not want to remain in the same position always.

Q4 The engineering curriculum at training institutions does not adequately provide students with soft skills education. Do you agree? Give reasons for your answer.

An engineering professional confirmed this problem by stating: 
"I do agree. Looking at the curriculum does not reflect that content. The students coming out of universities are not exhibiting such skills" (EP\#48).

The fact that this professional has 18 years of experience adds more weight to his opinion.

"I have to agree. The problem with the engineering syllabus, it's very full, crowded. Unfortunately, we have the tendency to bring new discoveries and new ideas and new work but not to weed out the old, so there is more and more work ..." (EP\#54).

\section{Q5 Evaluate the curriculum that you studied to become an engineer. Did it prepare you in terms of soft skills?}

\section{In disagreement:}

"Not at all" (EP\#8).

"No it didn't and I had to work hard to upgrade myself to be a rounded person" (EP\#46).

This answer seems a common theme among many other responses. The engineering practitioners expressed their dissatisfaction with the soft skills training they received at training institutions and spoke of how they had to struggle to acquire these on their own.

"No" (EP\#55).

"At diploma level, none" (EP\#52).

Q6 The engineering curriculum at training institutions should include soft skills. Would you support this move? Give reasons for your answer.

\section{In agreement:}

"Yes, especially now with the re-curriculation currently taking place" (EP\#24).

"Yes, I would support" (EP\#53).

"I think they should be included mainly because the work, for instance, is project-based. So every day there's a new project and these projects are actually done by diploma graduates" (EP\#52).

\section{In disagreement:}

"How do you teach someone theoretically to have teamwork?" (EP\#3)

The inconsistency is self-evident. For developing team work, one needs to work in teams.

The above respondent has mentioned the re-curriculation that is taking place within tertiary education currently. In engineering, this would see students spending less time as interns in the 
field before graduation, making a strong case for soft skills education to be included in their professional training.

\section{Q7 Do you think all lecturers can contribute to the teaching of soft skills? Or should only one lecturer be responsible?}

The findings for this question are similar to the questionnaire findings as well. Most engineering professionals are of the view that all lecturers should contribute to developing soft skills of their students:

"It should actually be part of your, I think the whole way in which you develop and present your programme should encourage soft skills from your students" (EP\#56).

“All lecturers" (EP\#4).

In fact, this is the view that the researcher has picked up, namely that if soft skills education is incorporated across the curriculum, there will be less cause for concern about time.

\section{Single lecturer:}

"Depending on the depth of the content, I would recommend one specialist lecturer. All lecturers cannot be master in this subject" (EP\#48).

Some were of the opinion that soft skills cannot be taught:

"N/A - can’t teach soft skills" (EP\#37).

Another similar response was:

"You must know that the engineering courses are some of the most difficult! One cannot add more to the curriculum" (EP\#49).

However, this engineering professional was a supporter of soft skills education:

"It would make the transition into the professional world easier" (EP\#49).

Therefore, what he has suggested is that the teaching of soft skills:

"... will have to be collective approach; there is too much work already" (EP\#49).

Q8 Engineering professionals also play other roles in society, for example, as citizens. Suggest ways on how they can be prepared for this while they are still students. 


\section{In support:}

A respondent made some very useful recommendations involving communities and young children:

"Teaching fellow community members during recess period on different solutions learnt from university e.g., environmental solutions like planting trees and sprinkler watering [rather] than hose pipe to save water. Teaching less privileged kids about team work and give them tasks that require team work, like waste management projects which are a problem in most African communities" (EP\#38).

"First and foremost, by leading by example. They can also visit schools and offer advice and motivational talks to learners" (EP\#27).

"Be involved with societies@ NMU/universities"(EP\#43).

"By means of an interactive process with a shadowing working professional" (EP\#55).

Engineers of the $21^{\text {st }}$ Century do not work on globalised projects alone. They need to plan their projects, identify their teams, organise resources, and deal with problems in collaboration with others. To perform these tasks effectively, they are expected to possess and practise more than technical skills. Research shows that employers are concerned about the lack of soft skills among young engineering graduates. These graduates assume that their future employers will provide them the skills necessary for their professional success. However, to save time and costs, employers are opting to employ graduates who already possess soft skills, in addition to their technical skills.

"As educators we must ask ourselves whether we are truly meeting the needs of today's young people to become engineers. Are we showing students what it really means to be an engineer? Are our young engineers prepared to successfully integrate knowledge from diverse areas of the sciences, mathematics, arts and humanities, and social sciences, to solve the complex problems that the world is facing?" (Steiner 2004, 1).

\section{CONCLUSION}

In conclusion, the study collected data from engineering professionals from all over South Africa to determine the value of soft skills in the engineering workplace and whether engineering training institutions in South Africa are providing adequate soft skills education to their graduates. For this purpose, the engineers were asked to reflect on their own training. The findings of the study reveal that soft skills education being provided at the engineering education institutions across South Africa is insufficient. To meet the demands of the contemporary work environment, it is critical for these institutions to provide holistic education to the future graduates by focusing on both technical and soft skills.

The study data shows that all participants agree engineers require soft skills in their 
professions (100\% of the engineering professionals agreed). A total of 92 per cent felt that engineers need more focus on soft skills because the engineers are predisposed to technical aspect of their professions. At least 84 per cent felt that the engineering curriculum that they studied to become an engineer did not prepare them in terms of soft skills nor did it provide adequate soft skills education ( $88 \%$ agreed). The problem could be that the curriculum is continuously being overloaded with new discoveries but the older parts are not "weeded out" and allowance is not made for soft skills education. As a result, the engineering graduates show a lack of these skills in their professions and have to work hard to acquire these skills.

The engineering professionals (88\%) stated that they would support the inclusion of soft skills education in the curriculum. Most of them (72\%) believe that all lecturers should be involved in the teaching of soft skills and not just one lecturer. They recommended that soft skills should be incorporated into the entire engineering curriculum and should be taught by all module lecturers. This would bring in multiple perspectives, as well as saving time. Even those who believed that engineering courses are already too difficult and that additional subjects cannot be added on, expressed the view that soft skills education would make the transition into the professional world easier for engineering graduates.

Regarding engineering professionals' role as responsible citizens, the engineering professionals who participated in this study recommended that students should spend time with community members or the less privileged children to teach them about environmental problems and solutions. Leading by example would certainly improve their own soft skills.

In view of the identified findings of this research, as well the literature review, it is important that we reflect on why the engineering curriculum offered is falling short in producing graduates with both state-of-the-art hard skills and the harmonising soft skills. Soft skills are key performance indicators when candidates are considered for employment and promotion opportunities. If this is the case, then the engineering curriculum should adequately address the need to prepare students for such opportunities. Professional engineers should be holistically educated, preparing them for life in the real world. The engineering professionals who participated in this study agreed that soft skills should be included in the engineering curriculum. Future research can address how to incorporate soft skills education into the existing engineering curricula. The message to education institutions, and specifically to engineering faculties and the Engineering Council of South Africa, is loud and clear: include soft skills in your curriculum if you want to produce a well-balanced human being who is also an excellent engineer. 


\section{REFERENCES}

Amadei, B. 2004. "Engineering for the developing world." The Bridge 34(2). http://www.nae.edu/ File.aspx?id=7306. (Accessed 15 March 2020).

BBC News. 2014. What is global warming? http://news.bbc.co.uk/cbbcnews/hi/find_out/ guides/world/global_warming/newsid_1575000/1575441.stm. (Accessed 12 October 2019).

Blesser, B. 2009. Soft skills predict professional success. http://www.blesser.net/downloads/Radio \%20World\%2027\%20Soft\%20Skills\%20Predict\%20Success.pdf. (Accessed 2 August 2018).

Bradford, L. 2017. 6 soft skills technical employees need to thrive. https://www.forbes.com/sites/ laurencebradford/2017/08/26/6-soft-skills-technical-employees-need-to-thrive/\#4b74e86b6b1d. (Accessed 4 March 2019).

Camuti, P. A. 2006. "Engineering the future: Staying competitive in the global economy." Journal for Global Engineering Education. http:/digitalcommons.uri.edu/cgi/viewcontent.cgi?article= 1000\&context $=$ ojgee. $($ Accessed 10 September 2019).

Carey, H. 2019. 5 Essential soft skills for a successful career in engineering. https://www.thomasnet.com/insights/5-essential-soft-skills-for-a-successful-career-inengineering/. (Accessed 3 April 2020).

Cisco Career Guidance. 2014. Technical ability alone is insufficient for engineering career success. http://learning.nil.com/cisco-career-guidance/business-skills-and-the-network-engineer/. (Accessed 12 June 2019).

Darby, A. 2020. What is engineering? https://www.bath.ac.uk/campaigns/what-is-engineering/.

Da Silva, A. F. and J. Tribolet. 2007. Developing soft skills in engineering studies - the experience of students' personal portfolio. In Proceedings of the International Conference on Engineering Education - ICEE, 3-7 September 2007. http://www.academia.edu/2307127/Developing_Soft_ Skills_in_Engineering_Studies_the_Experience_of_Students_Personal_Portfolio. (Accessed $\overline{9}$ June $201 \overline{9}$ ).

Del Vitto, C. 2008. "Cross-cultural 'soft skills' and the global engineer: Corporate best practices and trainer methodologies." Journal for Global Engineering Education 3(1): \#1. http://digitalcommons.uri.edu/ojgee/vol3/iss1/1. (Accessed 3 August 2019).

Development Policy Research Unit, University of Cape Town. 2006. Graduate unemployment in postapartheid South Africa: Nature and possible policy responses. http://www.btrust.org.za/ downloads/2_graduate_unemployment_in_post_apartheid_south_africal_mar2006.pdf. (Accessed 5 August 2019).

DPRU see Development Policy Research Unit.

ECSA see Engineering Council of South Africa.

Engineering Council of South Africa. 2020. What is engineering? https://www.ecsa.co.za/ engineeringsa/SitePages/What\%20is\%20Engineering.aspx.

Esterhuizen, I. 2013. SA's engineering science graduates increasing, but still below target - Nzimande. Engineering News. http://www.engineeringnews.co.za/article/sas-engineering-science-graduatesincreasing-but-still-below-target-nzimande-2013-06-18. (Accessed 17 March 2019).

Fourtané, S. 2019. Engineers should master soft skills for a successful career. https://interestingengineering.com/engineers-should-master-soft-skills-for-a-successful-career. (Accessed 14 March 2020).

Freedman, K. 2012. Engineers and Soft Skills. http://www.astd.org/Publications/Newsletters/ASTDLinks/ASTD-Links-Articles/2012/12/Engineers-and-Soft-Skills. (Accessed 20 May 2020).

Galloway, P. D. 2008. The 21st century engineer: A proposal for engineering education reform. Virginia: American Society of Civil Engineers.

Hissey, T. $\quad$ W. 2000. "Enhanced skills for engineers." In Proceedings of the IEEE 88(8). http://ieeexplore.ieee.org/stamp/stamp.jsp?tp=\&arnumber=880089. (Accessed 29 August 2019). 
Hissey, T. W. 2002. "Enhanced skills for engineers: Setting yourself apart with soft skills." Today's Engineer Online. http://www.todaysengineer.org/2002/Sep/skills3.asp. (Accessed: 29 August 2019).

Hodges, D. and N. Burchell. 2003. "Business graduate competencies: Employers' views on importance and performance." Asia-Pacific Journal of Cooperative Education 4(2): 16-22.

Huwart, J. V. and L. Verdier. 2013. "What is the impact of globalisation on the environment?" In Economic globalisation: Origins and consequences. OECD Publishing. http://www.oecdilibrary.org/docserver/download/0111111ec008.pdf?expires=1422196528\&id=id\&accname= guest\&checksum=CCA6DDFCBF3279E9F329678A1C57A8DC. (Accessed 12 October 2019).

Kaipa, P., T. Milus, A. Chowdary, and B. V. Jagadesh. 2005. Kaipa Group-executive summary. Soft skills are smart skills. http://kaipagroup.com/articles/softskills.pdf. (Accessed 20 September 2019).

Khalid, A., C. A. Chin, M. M. Atiqullah, J. F. Sweigar, B. Stutzmann, and W. Zhou. 2013. Building a better engineer: The importance of humanities in engineering curriculum. In Proceedings of the $120^{\text {th }}$ American Society for Engineering Education (ASEE) Annual Conference \& Exposition, 2326 June 2013. Atlanta. http://www.asee.org/public/conferences/20/papers/6052/view. (Accessed 11 July 2019).

Knobbs, C. G., E. W. Gerryts, and W. D. Roodt. 2013. "Programmes for developing soft skills in engineering students." In Proceedings of the 2nd Biennial Conference of the South African Society for Engineering Education, 11-12 June. Cape Town.

Llorens-Garcia, A., X. Linas-Audet, and F. Sabate. 2009. Strategic planning: Professional and interpersonal skills for ICT specialists. Computer.org/ITPro: IEEE Computer Society.

May, E. and D. S. Strong, D. S. 2006. "Is engineering education delivering what industry requires?" In Conference Proceedings of the Canadian Engineering Education Association. Toronto, Ontario, Canada. http://library.queensu.ca/ojs/index.php/PCEEA/article/view/3849/3844 (Accessed 14 October 2019).

McCarthy, M. A. 2013. Two approaches to closing the skills gap - one of which actually works. http://www.edcentral.org/two-approaches-closing-skills-gap-one-actually-works/. (Accessed 24 September 2019).

Miszalski, W. 2014. The influence of the global-scale phenomena and trends on the evolution of engineering education. https://www.wfeo.org/wp-content/uploads/stc-education/IDEAS_18__Impact_of_Globalization_on_Engineering_Education.pdf.

Moore, D. J. and D. R. Voltmer. 2003. "Curriculum for an engineering renaissance.” IEEE Transactions on Education 46(4). http://www.ece.uah.edu/ jovanov/CPE496/Curriculum_for_eng renaissance.pdf. (Accessed 4 June 2019).

Muller, B. 2010. Engineers "Made in Germany"- Technology from Germany. http://www.niederlande. diplo.de/Vertretung/niederlande/nl/06_Wi/_Research_20en_20technologie/Engineers_20Mad e_20in_20Germany.html. (Accessed 20 September 2019).

Nasr, K. J. 2014. Towards a converged and global set of competencies for graduates of engineering programs in a globalization-governed world. https://www.wfeo.org/wp-content/uploads/stceducation/IDEAS_18_-_Impact_of_Globalization_on_Engineering_Education.pdf.

National Academy of Engineering. 2004. The Engineer of 2020: Visions of Engineering in the New Century. Washington, DC: The National Academies Press. https://doi.org/10.17226/10999. (Accessed 17 March 2020).

Passow, H. J. 2007. "What competencies should engineering programs emphasize? A meta-analysis of practitioners' opinions informs curricular design." In Proceedings of the 3rd International CDIO Conference, MI, 11-14 June. Cambridge, Massachusetts, USA.

Pauw, K., H. Bhorat, S. Goga, L. Ncube, and C. van der Westhuizen. 2006. Graduate unemployment in the context of skills shortages, education and training: Findings from a firm survey. Development Policy Research Unit. https://open.uct.ac.za/bitstream/handle/11427/7345/DPRU_WP06- 
115.pdf?sequence=1. (Accessed 11 March 2019).

Stanford University. 2013. Working Paper 249. The quality of engineering education in the BRIC countries. http://fsi.stanford.edu/sites/default/files/Quality_of_engineering_education_in_the_ BRIC_countries.pdf. (Accessed 17 March 2019).

Steiner, M. 2004. "Using real-world multidisciplinary design experiences to prepare young engineers to enter today's workforce." In Proceedings of the International Engineering and Product Design Education Conference, 2-3 September 2004. Delft, Netherlands. http://www.designsociety.org/ publication/19652/using_real-world_multidisciplinary_design_experiences_to_prepare_young engineers_to_enter_todays_workforce. (Accessed 1 September 2019).

Teichmann, M., V. Parts, T. Kerikmae, M. Mart, and P. Aive. 2013. A heuristic model of non-technical competences for engineers. http://www.wseas.us/e-library/conferences/2013/CambridgeUK/ EDUCATION/ EDUCATION-05.pdf. (Accessed 9 June 2019).

The Royal Academy of Engineering. 2007. Educating engineers for the 21 st century. http://www.raeng. org.uk/publications/reports/educating-engineers-21st-century. (Accessed 20 September 2019).

The Sustainable Engineering Society of Australia. 2014. Engineering - Soft skills are not hard. http://seng.org.au/node/504. (Accessed 11 November 2019).

Vermeulen, A. 2013. Soft skills lacking in the workplace. http://www.engineeringnews. co.za/article/soft-skills-lacking-in-the-workplace-2013-07-26. (Accessed 10 August 2019).

Visser, H., L. Naude, and J. Scheper. 2004. Transformation of managerial skills of engineers. SA Journal of Human Resource Management 2(2): 17-23. 